\title{
MOTIVATIONAL UNDERPINNINGS OF ESTONIAN FOLK DANCE PRACTICES AMONG THE ESTONIAN DIASPORA OVER TIME
}

\author{
Eha Rüütel, Iivi Zajedova, Angela Arraste
}

\begin{abstract}
This article is a part of a wider research on Estonian folk dance, aiming to map the emergence of folk dance groups and to study the practices and role of folk dance among the Estonian diaspora. The article sets out to explore incentives contributing to intergenerational transmission of Estonian folk dance tradition. 54 interviews ( 21 men and 33 women aged 38 to 87 ) were carried out with Estonians living in Australia, Canada, Germany, Great Britain, Sweden and the United States. The analysis of the interviews is based on two research questions: 1) What incentives have guided Estonians' folk dance activity in historical perspective from World War II until today? 2) What qualities originating in Estonian folk dance have motivated people to carry on Estonian folk dance practices? The principles of grounded theory were used in the analysis of interviews. The article discusses the results of two sets of analyses. Motivational changes in folk dance as a leisure pursuit have brought into focus three historical periods of folk dance transmission. Incentives originating from dance and dancing (selfexpression, self-determination, cooperation, emotion, physical training) and the external qualities accompanying dance and dancing (socialising, 'Estonianness', tradition) are discussed in the context of continuity of Estonian folk dance tradition among the Estonian diaspora.
\end{abstract}

Keywords: folk dance, Estonian diaspora, leisure activities, self-determination, motivation, cultural transmission

\section{INTRODUCTION}

In many written works that describe expatriate Estonians, folk dancing has been mentioned as one of their leisure activities (Kokla et al. 1956; Kool 1999) and therefore many publications that have come out abroad have listed folk dance groups of Estonians and their activity in different countries (Purje \& Varangu 1984; Jõe 1985; Kangro 1976). This article aims to give an insight into the continuity of folk dancing and the factors facilitating it among the Estonian diaspora. An important background factor was the popularity of folk dance as a leisure pursuit during the period of Estonian independence before World War 
II. Schools and temperance societies had an important role in popularising folk dance practice. The roots of Estonians' folk dance hobby reach back into history. The folklore studies of Põldmäe and Tampere (1938) refer to men's prebattle ritual dance in the 12th century and recreational dancing (dancing for pleasure) in the second half of the 19th century at swinging sites, communal work events, village parties and weddings. In the early 20 th century it became habitual to perform folk dance as a part of party programmes, whereas dance functioned as a means of communication between the audience and performers. An increase in the popularity of group dancing gave rise to the introduction of more interesting staging techniques. As a result, in the years 1904 to 1926 a performance-focused orientation developed in the Estonian amateur folk dance. Aassalu (1999: 4) emphasises the landmark event in the Estonian folk dance movement - the Evening of Indigenous Culture in 1926. Its typical features also characterise modern dance celebrations (Arraste 2009). It is maintained that the Estonian tradition of folk dance celebrations ${ }^{1}$ was initiated by the First Estonian Games ${ }^{2}$ held in 1934. Thus, before World War II, folk dance had developed into an appreciated area of activity and a popular leisure pursuit, and collecting dance descriptions and methods had started. Kangro ${ }^{3}$ (1976) views the ancient tradition of Estonian folk dancing and its rich repertoire of more than 200 old folk dances as an internal precondition for the continuity of folk dancing as a leisure activity. Anna Raudkats, a promoter of folk dance, on whose initiative folk dance became an essential part of physical education classes at school, viewed dance as a pleasant pastime, which made dancers forget their daily problems and developed the feeling of togetherness in them (Raudkats 1926; cited in Vissel 2004). Amateur dance pursuit was considered very important, because it deepened the love for ancestors' intellectual creation and at the same time kept people healthy, improving their physical and mental stamina, stimulating their emotions and giving them strength (Põldmäe \& Tampere 1938: 50).

The Estonians who fled their homeland as war refugees during World War II, left mainly for Germany and Sweden, where they were concentrated in camps. Many Estonians later moved on to other European countries, America and Australia. For most of those who fled to Germany, refugee camps provided their first shelter and housing for several years. There were refugee camps also in Sweden but the length of stay there was short - only a month or two.

Due to the war and the changing political situation, it was professionally and socially active people who left Estonia. However, only few people were engaged with everyday work at refugee camps, which left plenty of leisure time. According to Russell (2009), the contemporary meanings of leisure can be categorised in three ways: as free time, as a recreational activity, or as a state of mind, a 
special attitude or feeling. Leisure as a state of mind is an entire lifestyle that produces meaningfulness in life, self-expression, and self-actualisation. McGill (1996) states that leisure helps to describe how people view themselves; active leisure involvements give a stronger sense of who they are and enhance their sense of belonging.

The above allows for creating a connection with self-determination theory (Deci \& Ryan 2000, 2008; Ryan \& Deci 2000), which assumes that people are by nature active and self-motivated; however, social conditions and processes have an impact on what people do and how they feel while acting, and, as a consequence of acting, social environment either supports, directs or thwarts that nature. Social contexts that facilitate the satisfaction of three basic psychological needs - to feel competent, autonomous, and related to others - support people's inherent activity, promote more optimal motivation, and yield most positive psychological, developmental, and behavioural outcomes (Ryan \& Deci 2000; Deci \& Ryan 2008).

As in the pre-war period folk dance practice had developed rapidly and folk dance skills were a part of education, there were many Estonian refugees who had relevant experience and were able to organise and lead folk dance groups. Little professional engagement made people look for activities to fill their time and created an opportunity to continue pursuits that had become habitual at home, and thus to maintain continuity, give meaning to the time spent at refugee camps and sustain hope to return to homeland. Therefore Estonians residing at camps filled their lifestyle-related leisure with cultural and social activities (Kokla et al. 1956: 88).

As an embodied leisure practice, dance has been described by the capacity to create cultural identity (Shoupe 2001; Snape 2009) and, as Snape (2009) emphasises, in developed countries folk dance tends to be performed not only for its intrinsic enjoyment but also because the dancers engage, to varying degrees, in the preservation or re-creation of a national or regional tradition. However, active participation in Estonian folk dance activities in the refugee camps was obviously due to the fact that many people had learned folk dance before. Revill (2004: 8), while analysing folk dance pursuit and relying on a set of personal reminiscences drawn from his own experience of learning French folk dance, attaches importance to dancers' hard work, which precedes the dance-related self-expression and enjoyment of movement:

[...] practising for the moment at which their activities are miraculously transformed into unreflected habit. [...] That moment is charged as an originary and foundational moment from which a more truthful cultural practice emerges. 
Revill emphasises connections between body culture, history and social values, and the free and authentic interaction taking place while dancing and through the medium of dance.

Dancing profoundly socializes the body, from the embarrassment of excess perspiration to the blur of self-contained exhibitionism as couples pirouette at speed around the room confident in their mutual trust. The dancing body communicates and speaks volumes in response to others. (ibid.: 9)

While describing the spread of folk dance hobby among Estonian war refugees, Kangro (1976) highlights as the most important in the specific situation the energy, enthusiasm and buoyancy as well as trust in the future, to dance, exercise and take part in physical activity in spite of the challenging status of being a refugee. In this process, the performance of folk dance acquires a layered meaning and becomes a conscious symbolic act, representational of something beyond its immediate occurrence (Snape 2009).

This allows us to state that in spite of the drastic political and psychological context and ascetic conditions of refugee camps, these circumstances mobilised the Estonian community and maintained the folk dance tradition. Kangro (1976) emphasises that, in addition to the internal prerequisites, favourable external conditions were needed, i.e., sufficiently compact groups of people living reasonably close to each other, and the availability of rooms for meeting, practicing and performances. Communal activity also supports general and personal coping. Those who enjoy a high level of social support experience less adverse effects of stress (Cohen 1991). On this basis, the folk dance practice of expatriate Estonians can also be considered as an activity promoting health and well-being in terms of physical training, social support network and self-determination.

The current article is a part of a wider research on Estonian folk dance, aiming to map the emergence of folk dance groups and to study the practices and role of folk dance among the Estonian diaspora. The aim of the article is to describe general motivational underpinnings contributing to the survival of Estonian folk dance tradition among the Estonian diaspora in Australia, Canada, Germany, Great Britain, Sweden and the United States. The analysis of the interviews carried out with Estonians is based on two research questions: 1) What incentives have guided Estonians' folk dance activity in historical perspective from World War II until today? 2) What qualities of Estonian folk dance have motivated people to continue dance practices? 


\section{METHOD}

\section{Participants}

First contacts with local Estonians in six countries (Australia, Canada, Germany, Great Britain, Sweden and the United States) were established through Estonian societies and Estonian folk dance groups. During the interview process and conversations, information about other people possibly involved in folk dance was obtained. Altogether, 54 interviews were conducted with 21 men and 33 women from three generations of Estonians during the years 2006-2010: four living in Australia (one man and three women aged 48 to 71); four in Canada (three men and one woman aged 50 to 87); thirteen in the Federal Republic of Germany (six men and seven women aged 46 to 85); seven in Great Britain (one man and six women aged 36 to 84); eleven in Sweden (six men and five women aged 28 to 80 ), including two Swedish Estonians who had returned to Estonia; fifteen interviews were conducted with Estonians from the United States (four men and eleven women aged 52 to 76), including one who currently lives in Estonia.

\section{Data collection and analysis}

Unstructured interviews and conversations were used. All interviews were videotaped and transcribed, maintaining, as far as possible, without loss of meaning, the original form of the text and use of language. To present the results, the following symbols have been used to refer to interviewees: initials and, in brackets, the age of the interviewee at the time of the interview, gender (F - female, $\mathrm{M}$ - male) and country of residence (A - Australia, C - Canada, G - Germany, GB - Great Britain, S - Sweden, USA - the United States of America).

The principles of grounded theory (Glaser \& Strauss 1967; Strauss \& Corbin 1990) were used in the analysis of the transcribed texts. Grounded theory strives to arrive at a theoretical understanding of psycho-social phenomena, which is grounded in the data collected from the lives and contexts of the participants (Forrester 2010). Grounded theory starts with details of individual cases and uses the logic of induction to develop a theory that holds true for those cases (ibid.). The researchers started with independent open coding of the interviews and creating country-based categories. The results of the analysis were compared and, if necessary, interviewees were asked clarifying questions. Grounded theory allows for starting the collection of data to describe the researched phenomenon without a prior theoretical approach. Therefore the literary sources 
given in the introduction of this study constitute the materials used to describe the context rather than the theoretical basis of this research.

The first study was carried out in Germany, which was the first stopover for Estonian refugees, from which they moved on to other countries, and described the categories related to Estonian folk dance in this country (Zajedova \& Rüütel 2009; Zajedova et al. 2009).

I. Places where people danced: a) refugee camps, b) summer camps / summer homes and scout camps, c) folk festivals, d) performances, c) political demonstrations.

II. Motives (what made people dance): a) hobby continuity, b) living together in a refugee camp, c) entertainment, d) a desire to teach folk dance to children.

III. Activities of folk dance groups (how folk dance groups operated): a) activity, b) support, c) groups and interests, d) benefits of folk dance.

The second step was a comparative research of Germany and Sweden (Zajedova \& Rüütel 2012). The study revealed aspects contributing to contrasting situations - the demise of folk dance groups in Germany and the sustainability of folk dance activity in Sweden. In both countries the set-up and organisation of folk dance groups relied largely on enthusiasts and participation in folk dancing was used as a good possibility for bringing young people together. However, certain differences can be observed. In Germany folk dance activity seemed to be influenced to a large extent by cultural-political objectives, the topicality of which diminished when Estonia regained its independence. In Sweden, the popularity of folk dance seems to have been maintained due to the modernisation of the dance style, which became more choreographed and show-like, and thus more interesting and attractive to young people.

In the third stage of the study the German and Swedish interviews were complemented by the ones conducted in Great Britain, Canada, the United States and Australia, and the cultural celebrations that had taken place in different communities of the Estonian diaspora were mapped on the basis of literary sources and archival materials (Arraste \& Zajedova \& Rüütel 2011). It described the dimension of cultural celebrations (local, regional, worldwide), changes in the dimension and diversification due to local developments as well as wider spread of information after Estonia regained independence in 1991. The study of cultural celebrations clearly showed that although after World War II the Estonian nation was geographically fragmented into Estonians abroad and Estonians at home, their major celebrations belong to a coherent whole and carry the continuity of the Estonian national culture. 
This article reflects the fourth stage of the research and focuses on the motivational underpinning of Estonian folk dance practices. Since the interviews included a wider range of topics than the objectives of this article, the first step was to identify conceptual categories relevant to the research questions of the current article. Through axial coding individual categories were grouped into the main categories of motives, first in a historical perspective and, second, based on the qualities of Estonian folk dance.

\section{RESULTS}

\section{Changes in folk dance as a leisure pursuit over time}

The analysis of the interviews reveals three periods, different in their circumstances, objectives and incentives. The first period covers the time when the Estonians who had emigrated lived in refugee camps in Germany and Sweden. The second period includes the time from the liquidation of the camps in 1949 to the restoration of independence of Estonia in 1991. The third period views today's folk dance activities.

\section{Period I: Folk dance in refugee camps as a part of daily life}

The initial stopover for Estonian war refugees was refugee camps in Germany and Sweden. In Sweden Estonian refugees lived in these camps for a short period only and were distributed across the country, from where in the 1950s the majority settled in towns (Kokla et al. 1956). The stay of the refugees in German refugee camps was longer and the camps were acting as a meeting place for those Estonians who lived outside.

GB (63F, G, not a former refugee camp resident): There were masses of them, [...] who lived in the camps. [...] Some were in the suburbs of Hamburg, some were a little further. [...] We always met up with them. They invited us and when there was a Christmas party, the anniversary of the republic, or a summer festival, we always went and sang and danced. [...] In Oldenburg there were also big camps and there they lived together and danced, sang together.

$\mathrm{LP}(85 \mathrm{~F}, \mathrm{G})$ : We had a young man who [organised] gatherings of refugees for at least twice a month, I think. There we danced and sang and baked cakes and everyone had to do something. 
Community life included dancing as a regular activity and the camps became the first places for the formation of folk dance groups.

JK (81M, G): In the camps, everywhere where there were Estonians [...] people sang and danced. [...] Where we lived, well, the houses were very close to each other; it was such a primitive communal space. We gathered there and practised. [...] It made us work harder, to keep body and soul together, [...] this means, at weekends, then.

Research revealed that the activists and leaders of folk dance did not necessarily have any special training, but that it was rather the desire to dance and teach folk dance to their children that stimulated them to learn and study dances and teach them to other people.

MB (68F, A): All that boy scouts and girl guides' thing, folk dance and choirs - they had strong tradition in refugee camps. Some men went to work, but not all. Women very seldom worked. So there was plenty of free time to teach young people folk traditions. [...] Then, when they spread all over the world, they started folk dance groups and choirs, the Scouts and Guides' and sports groups.

The repertoire seemed to vary according to the skills and knowledge of the leaders of the dance groups. First, folk dances were practised from memory, because the representatives of the older generation had learned folk dances at school in Estonia. After the publication of Ullo Toomi's" (1953) book "Estonian Folk Dances", this was used to teach folk dance in Estonia and abroad.

JK (81M, G): I came across this thing at a pretty young age indeed. I finished primary school in Viru-Jaagupi and the last grades I attended in Viru-Jaagupi when I was 11 to 14 years old, and they taught folk dance there already at that time.

VJ (61F, G): I had an aunt [...] She was teaching Estonian dance [in Hamburg], but these were not proper folk dances. It was a little bit like [...] done her own way.

GB (63F, G): We had that book [Ullo Toomi's "Estonian Folk Dances"] and we took our repertoire as we were told. [...] We learned and mastered them. [...] Well, there was always someone who knew [...] how it went. 


\section{Period II: Folk dance as a carrier of the continuity of Estonian identity}

The second period is related to the realisation of people that the expected imminent return to Estonia was not going to happen and it was necessary to organise their lives for an extended stay abroad. This period is also associated with the movement of Estonians from their initial stopovers to the United States, Canada, Australia, and Great Britain. The keywords defining the second period are Estonian communities passing Estonian culture on to children, and folk dance as national self-expression and part of national self-determination.

Estonians considered it important to create Estonian communities in their countries of residence; Estonians in America emphasised the term "Estonian village".

$\mathrm{AE}$ (86F, GB): [...] when they came here, a large group of Estonians [...] there was a choir, a dance festival. It was all like ... like a small Estonia. The same as in Germany and Canada and everywhere else ...

VA (76M, USA): Well, there was Estonian culture [...] there had to be everything in the Estonian village, folk dance and choirs.

The interviews highlighted that folk dancing was a popular leisure activity among expatriate Estonians; popular enough to find a sufficient number of interested people to join folk dance groups. Practice and rehearsals took place on a regular basis.

Children's folk dance groups were formed in order to pass on knowledge and traditions to the next generation. In Germany, interviewees devoted considerable attention to children and youth summer camps, in which Estonian children communicated with each other in the Estonian language and where they also learned folk dances. Estonian folk dances were taught on a regular basis at Estonian schools in Australia, Canada, Great Britain, Sweden and the United States, ${ }^{4}$ and folk dance was integrated into the teaching of Estonian culture.

MB (68F, A): During my school days I lived in an English-speaking world from Monday to Friday. From Friday evening to Monday morning I lived in an Estonian-speaking world with the continuation school, the Scouts and Guides and gymnastics and folk dance. But it wasn't an official group as such. This was just part of our national education.

Performances of folk dance groups allowed to introduce Estonians and Estonian culture to the local people in the countries of residence. Through folk dance Estonians expressed their national character, defined themselves in their new 
cultural environment. The performances took place during 1) the local events of the Estonian community, which were mainly related to Estonian holidays or those of the country of residence, events introducing and uniting the Baltic nations as well as other nations on a wider scale; 2) national reunions of expatriate Estonians (e.g. Estivals in Sweden, West Coast Days in the United States); 3) worldwide festivals for expatriate Estonians (ESTO). Before performances, practice sessions were more frequent and more attention was paid to the accuracy of the presentation. During performances Estonia and Estonians were introduced, speaking about who they were and why they were there.

HA (50M, C): [...] In Canada, be it a multicultural day, or be it ESTO days, there was always a procession in the centre of the town related to it. We were walking with flags and posters, wearing national costumes, Scout uniforms or whatever groups had come.

The performances could also acquire strongly political undertones:

LP $(85 \mathrm{~F}, \mathrm{G})$ recalls: Choirs and folk dance [...] that was our weapon. [...] We were not allowed to do politics in Germany but we could do cultural politics and by means of that we still managed to introduce our culture, our songs and dances, our Estonian language. [...] I hold that this was our weapon for restoring independence, our contribution.

The second period is characterised by actively functioning Estonian communities and the preserving and maintaining of the Estonian language and culture. In passing down the Estonian traditions to children, learning the language was of primary importance. The teaching of folk dance was integrated into the general instruction on Estonian culture, and children acquired skills in folk dance and folk singing at an early age, in summer camps and Estonian schools.

\section{Period III: Folk dance as an artistic-cultural self-expression in the multicultural environment}

The third period began when Estonia regained independence in 1991. It was possible to freely visit Estonia, participate in dance festivals, communicate with folk dancers, and learn from Estonian folk dance leaders. Joint folk dance study days and seminars were organised. Judging by the interviews, it seems that folk dance is not so much an integrated part of the general national culture and being an Estonian. Today's folk dancers are the third generation of Estonians whose home language is often not Estonian, and non-Estonians interested in folk dance are included in the groups, hence the role of folk dance in preserving 
the Estonian language is no longer valid. Discovering Estonia by the Estonians of the younger generation seems to occur on a wider scale than just national culture and does not necessarily involve folk dance activities.

The emphasis in Estonian folk dance seems to have shifted on artistic selfexpression. To preserve and develop that, motivated dancers are needed.

LT (51F, USA): The numbers in new generations get smaller all the time [...] I hope they (Americans) like our company, [...] and we are so grateful when they come [and dance]. But if there were only Estonians, if there were four couples of us, we would dry up very rapidly.

Changes have also taken place in the teaching of folk dance. Summer camps for dance leaders are organised and active communication takes place between Estonian folk dance professionals all over the world.

LT (51F, USA): For the first time the dance leaders' group met in 1995. [...] I've been to two summer camps of dance leaders. [...] And now I have several dance leaders in Estonia, from whom I can ask when I need help [...] and I have some people to discuss my ideas with. This exchange of ideas [...] I'm very grateful for that.

The third period covers the functioning of Estonian communities and their cultural traditions in the context of openness created by Estonia's regained independence and rapidly developing information technology, which makes it easy to maintain and establish contacts and participate in Estonian culture. The earlier traditions of passing down cultural phenomena do not fit for the changed circumstances, therefore this period seems to be characterised by a retune to multiculturalism. The following analysis of the incentives of the Estonian folk dance activity is an attempt to open these background factors that in the current conditions support the continuation of Estonian folk dance in the expatriate Estonian communities.

\section{Incentives for Estonian folk dance activity}

The following analysis reveals the context of folk dance performance and interviewees' relationship with folk dance, leaving aside the aspects of repertoire, music and choreographic expression, which have been described in the earlier published articles (Arraste \& Zajedova \& Rüütel 2011; Zajedova \& Rüütel 2009, 2012; Zajedova et al. 2009). In the current analysis the Estonian folk dance is viewed in its widest sense, based on the interviewees' personal definition and relationship with folk dance. Thus, the authors do not take on board the problem of defining folk dance, which is seen by the researchers of the field as 
a complicated issue due to the changes in the dance culture and, even more, in the way of thinking (Kapper 2009). At the same time, it is probably important to give here the description of the nature of Estonian folk dance that appears on the webpage of the non-profit association Estonian Traditional Music Centre:

Estonian folk dance has been viewed as collective, restrained and dignified, striving for no external effect. There are no big leaps in the dances or fast and varied activities of arms and legs. The body is usually kept straight and there are no hip movements, as is characteristic of many modern dances. Arms are usually not raised above the hip level; movements requiring grace and flexibility, such as foot stretches, deep bends or high leg lifts, are unknown. (Eesti tantsu iseloom 2009)

\section{Qualities originating from dance and dancing}

Cultural-national self-determination. In the process of learning folk dances, knowledge was also acquired about Estonia, the regions that the dances came from, and dance traditions; the history of Estonia was learned through dances of various periods. This gave material for reflection about one's belonging, one's roots. Large festivals provided Estonians with an opportunity to explain and show Estonian culture to the audience.

TA (48F, A): I think that everyone needs to know where he or she comes from. [...] It is very important for every person. [...] In recent years we've been trying more and more to perform in Australian multicultural events, National Folk Festival has been the largest, [...] to perform Estonian dance, because it's a bit different, and to place Estonian culture in the multicultural image of Australia. Estonians also belong to Australia, we have something that is original, that is different and interesting. That while being Australians we are also Estonians...

RM (59F, C): [...] and friendship and interest in Estonia, and you're learning not only dances, you're learning Estonian music, Estonian geography through realising where these dances have come from. Again, in Toomi's ${ }^{5}$ book it's been very accurately described where a dance comes from, and the pride - to wear the national costume with pride. [...] We knew exactly where the national costume of each of us came from.

Dance as a language of self-expression includes codes, such as 'dance as a type of culture', 'tool of communication' and 'mediator of culture'. The interviewees 
attached importance to dance as a universal language and emphasised that dance is a national activity in which one can be involved even without any knowledge of the Estonian language.

TK (52F, USA): I've always thought that heritage is a much wider thing. [...] Expatriate Estonians may have limited this understanding a bit too much. That it had to be based on the language. But we had folk dance that wasn't directly based on the language. So then, because it survived, because this pleasure survived, I think it is another example that culture can be mediated in different ways. [...] And through that I've learned to dance so well that I enjoy it.

MB (68F, A): We have many young people, especially in Sydney, who don't speak a single word in Estonian. But folk dance is such a national activity that you can engage in without knowing the language. I'm not surprised that folk dance is the part of our national activity that has survived best. When you've lost the language you can still dance.

Cooperation. The category of cooperation includes group qualities outlined in the interviews, such as 'holding together', 'the group feeling', and 'joint performances'.

TK (52F, USA): When I grew up, I danced because I wanted to do it. Then we developed this really nice feeling of the group, the group feeling. There was the pride that we were able to be in tune with each other, that we were good at it.

Emotion. As the majority of expatriate Estonians had danced since childhood and they knew how to dance, positive emotions accompanying performances were emphasised; the participants enjoyed dancing, folk dances were described as merry dances. The performances offered the audience the pleasure of dance patterns.

TK (52F, USA): I think it produced beauty in the old, ancient sense. It was fun and joy of movement with music. Sense of beauty through the costumes, dance patterns, and working together. It produced the beauty you can only find in folklore.

MB (68F, A): Folk dance was fun, a nice thing. It wasn't like we had to dance absolutely perfectly. When you're young, you remember all the movements. And when you're dancing with your friends, and it's your weekly activity, and there's a performance approaching - it's great. I cannot think of a better time. 
Physical activity. The interviewees also emphasised the physical quality of dance practice - 'good feeling', 'physical fitness', and 'body control'.

AS (87M, C): [...] two things: for fun and physical training and that was probably one of the most important things, that physical training, wasn't it? And [body] co-ordination, of course. So that you're able to move your hands and feet.

MB (68F, A): But in our time we simply danced and I was very proud of it that my partner and I, that we were the champions of South-Australia, that we danced the Jooksupolka $a^{6}$ for at least 22 times around the hall of the Estonian House without getting breathless. [...] It was physically very rewarding.

\section{The external qualities accompanying dance and dancing}

The external qualities of dance and dancing are related to communication and the circle of people that met during dance practice sessions.

Socialising. Holding together and supporting each other were very important for the Estonian war refugees in order to cope in their countries of residence. More recent folk dance pursuit is largely viewed as an opportunity for entertainment and socialisation, meeting with the people you know, making new acquaintances. As an important stimulus, finding an Estonian partner was mentioned.

AR (61M, S): Let's say that among Estonians in Gothenburg those who were active often participated in several organisations and kept meeting, so to speak, under different 'umbrellas'. One evening we would meet as part of a student society, the next day as part of a sports society and on the third evening we were folk dancers.

RJ (50F, GB): The friends I made there have been my friends ever since. [...] Just that it was fun meeting other young Estonian people and do something together. Indeed, we had always so much fun and I was really looking forward to these practice sessions.

'Estonianness'. This category describes the national-historical context of Estonian dance and the perception of one's roots through dance, as well as knowledge about, experience of and connection with Estonia. 
IW (62F, GB): It maintained Estonianness in me. And that's why I think I'm much more interested in Estonia and dance festivals and folk dance and folk music than I would've been without doing it in my childhood.

RL (56M, S): To me it gave a lot, to be able to do things with other Estonians. To do Estonian things, so to say.

Tradition. The ability to dance and practice Estonian folk dance was viewed as an Estonian tradition that belongs to the daily life of Estonians and constitutes a part of the overall education.

PS (55M, GB): In the old days, before Estonia became free, it was a way of keeping the traditional life [...] It's like keeping it going for the people who hadn't gone back to Estonia or who'd left before the war or during the war. It's keeping that tradition going for them... Things have changed in England a lot during years, since Estonia became free, but we still keep that old tradition going. [...] It's a good feeling to meet other European Estonians. A good feeling.

$\mathrm{MB}$ (68F, A): [...] we didn't seem to have that choice. It never even occurred to me not to do that. We had a very nice group. We were all together in the continuation school, we were all in the Scouts and Guides...

AR (61M, S): Folk dance belongs to the general education of intelligent Estonians.

LT (38W, GB): I like it so much. I like watching and dancing. I don't want it to die off.

The incentives for Estonian folk dance activity are summarised in the two figures below. The analysis of the personal incentives of the transmission of Estonian folk dance practices reveals two categories (Figure 1).

Both categories seem equally important for the transmission (dancer's aspect) and preservation (teacher's aspect) of Estonian folk dance activity. Focusing on Estonian dance as a medium of identity and culture, we can present three main categories that emerged during the analysis of the interviews: interest in dancing, community (meaningful emotional relationships) and 'Estonianness' (knowledge about, experience of, the connection with Estonia) - the essential component that ensures the originality, the typically Estonian quality of Estonian folk dance (Figure 2). The language of Estonian folk dance serves as the mediator between generations. 


\section{Qualities related to Estonian folk dance}

Qualities originating from

dance/dancing:

- Self-expression through dance

- Cultural-national self-determination

- Cooperation

- Emotion

- Physical training

\section{Qualities accompanying}

dance/dancing:

- Socialising

- 'Estonianness'

- Tradition

Figure 1. Qualities originating from dance and dancing and related qualities that underpin folk dance practices.

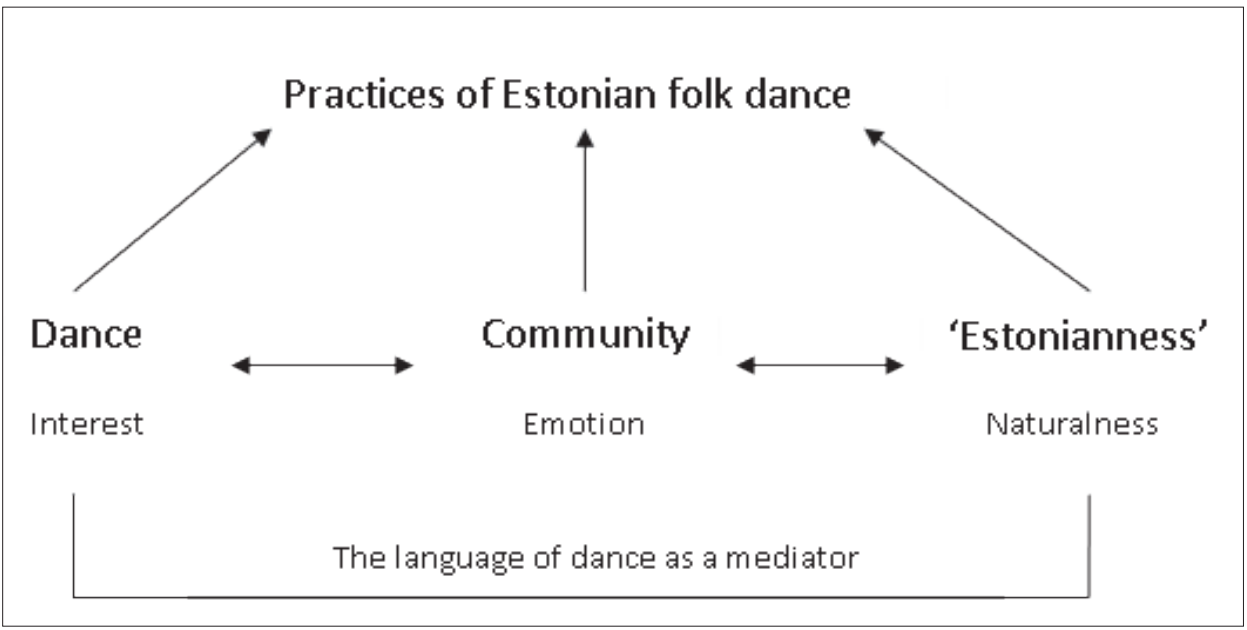

Figure 2. Main incentives underpinning the continuation of Estonian folk dance practices. 


\section{DISCUSSION}

The aim of this study was to explore the motivational underpinnings that have contributed to the survival of Estonian folk dance tradition in Australia, Canada, Germany, Great Britain, Sweden and the United States. A chronological analysis of the data revealed three periods. The first period covers Estonians' life in refugee camps in Germany and Sweden after World War II until 1949. The general incentive in that period, which also applies to folk dance, was starting life in the new countries of residence. The factors contributing to adopting folk dance as a leisure activity were: people's earlier experience of folk dancing for recreation, and the proximity and little employment in the camps that left people with plenty of free time. Priority was given to young people's national education, which also included folk dance. The interviews referred to the emotional side of folk dancing as an enjoyable social pastime. As Cohen (1991) has emphasised, social relations have a positive effect on well-being. Dance and music have been considered as directly "mood-inducing" activities (Argyle 1999). Thus folk dance seemed to have an important role as a physical activity and also an activity bringing people together and providing space for communicating, with an addition of aesthetic enjoyment from the colourful folk costumes. Thus the health-promoting role of folk dance observed by Kangro (1976) cannot be underestimated. Based on the identity-developing potential of leisure (Shoupe 2001; Snape 2009), the important effect that national cultural leisure activities in refugee camps had on cultural self-definition can be observed over time.

The main incentive for the second period lasting until Estonia regained independence in 1991 was the preservation of the continuity of 'Estonianness'. The interviews reflected responsibility for the transmission of Estonian culture, and especially the Estonian language. Folk dance was integrated in children's cultural education. In dance classes the Estonian language was spoken and thus learning Estonian dance also contributed to language acquisition. Folk dance allowed introducing Estonians' ethnic origin, expressing political views, and attitude towards the occupation of Estonia.

The third period that involves the past couple of decades is characterised by the fact that national borders are no longer a barrier between expatriate Estonians and Estonian culture in its diversity is available in many places in the world. Today dance-specific incentives dominate - self-expression through dance and professionalism in dance as well as the opportunity provided by the dance, which Revill (2004) points out as a language that combines culture, history and social values. 
However, there are considerably fewer people practicing Estonian folk dance than in earlier periods and, due to the change of generations, non-Estonians have joined folk dance groups. The need to preserve the Estonian language through folk dance seems no more the basic motive for folk dance activity, although the question of language has always been a sensitive contact area between the conservatism and rational practical behaviour of expatriate Estonians (Kõiva 2010).

According to the self-determination theory (Deci \& Ryan 2000, 2008; Ryan \& Deci 2000), it is important what people feel while acting. Behaving with full sense of volition and choice presupposes autonomous motivation, which comprises both intrinsic and well-internalised extrinsic motivation. We can provisionally define the qualities originating from dance and dancing (self-expression, self-determination, cooperation, emotion, physical training) as a source for intrinsic motivation and the external qualities accompanying dance and dancing (socialising, 'Estonianness', tradition) as internalised extrinsic motivation. In case external motives dominate, the importance of the dance component decreases and besides or instead of dance it is possible to find other activities fulfilling the same purposes and needs. When dance qualities dominate, the connection weakens with the wider socio-cultural context, which carries the traditions of Estonian folk dance and components of social recreation. Thus the interest in dance, folk dance community and 'Estonianness' in the meaning of knowledge, experience and connection with Estonia can be considered as the main carriers of the continuity of Estonian folk dance tradition.

\section{CONCLUSION}

The interviews revealed that Estonian folk dance is viewed as a traditional activity, which still belongs to the daily life of expatriate Estonians and is a part of being an Estonian. Folk dance as leisure activity supports people's need to belong, their self-esteem and importance as contributors to a group's success. In other words, as Põldmäe and Tampere put it: "Individual participation in group activities enabled to get the experience of perceiving the nature of mass as a whole while appreciating the role of an individual in human society" (Põldmäe \& Tampere 1938: 50). Apparently these were the reasons for many young and older people to dance in post-war years, when maintaining the ethnic identity and self-determination in a new cultural environment was important. This also explains why currently the number of people practicing Estonian folk dance has decreased. The opportunities for self-determination and belonging have 
expanded due to people having adjusted in the countries of residence and due to the improved connection with Estonia.

Focusing on personal incentives that have maintained the folk dance activity of expatriate Estonians over the years, this study reveals the variability of human motives, which sheds light on the multi-layered personal and social role of folk dance among expatriate Estonians.

\section{ACKNOWLEDGEMENTS}

We would like to express our gratitude to the expatriate Estonians who participated in our study and contributed to the successful completion of our research. This article reflects the results of the study carried out within the framework of grant No. 7231 of Estonian Science Foundation, "The original choreographic text and form of presentation of Estonian folk dances as fixed in audiovisual recordings".

\section{NOTES}

1 Estonian Song and Dance Festivals - large-scale festivals held every fifth year, assembling as many as 40,000 singers and dancers. In 2008, Estonian Song and Dance Festivals were inscribed in the Representative List of the Intangible Cultural Heritage of Humanity (originally proclaimed in 2003) (see http://www.unesco.org/ culture/ich/index.php?pg=00011\&RL=00087).

2250 folk dance pairs performed at the great gymnastics and sports festival in Tallinn in 1934, which has also been regarded as the first Estonian national dance celebration, and which by now has become a simultaneous event with our Song Festivals.

3 Bernard Kangro (1910-1994) was an Estonian writer and poet who formed the quintessence of exile literature.

4 The Estonian school was functioning in Stockholm during World War II and it still operates successfully. The Estonian school in Gothenburg was opened in 1960 but was shut down in 1994 due to lack of teachers and children. Estonians started educational life also in German refugee camps and later on in other countries, such as Australia, Canada, Great Britain, and the United States. Estonians mainly established Estonian Sunday and Summer Schools.

5 Ullo Toomi (1902-1983) was a teacher of Estonian folk dance in Estonia and authored a book entitled Eesti rahvatantsud (Estonian Folk Dances).

${ }_{6}^{6}$ Run-run-jump dance. 


\section{MANUSCRIPT SOURCES}

Interviews and field notes from Bocholt, Germany, 2006; Hamburg, Germany, 2007; Gothenburg, Sweden, 2007; Birmingham, UK, 2008; Tallinn, Estonia, 2008; Portland and Los Angeles, USA, 2009; Washington, USA, 2009; Annaberg, Germany, 2009; Toronto, Canada, 2007 and 2009, in the possession of authors.

\section{REFERENCES}

Aassalu, Heino 1999. Murrangud eesti rahvatantsus ja harrastusrahvatantsus. [Upheavals in Estonian Folk Dance and Hobby Folk Dance.] Tallinn: Rahvakultuuri Keskus.

Argyle, Michael 1999. Causes and Correlates of Happiness. In: Daniel Kahneman \& Edward Diener \& Norbert Schwarz (eds.) Well-Being: The Foundations of Hedonic Psychology. New York: Russell Sage Foundation, pp. 353-373.

Arraste, Angela 2009. Enne suuri pidusid. [Prior to Large Festivals.] In: Ilma Adamson \& Anneli Ammas \& Lille-Astra Arraste \& Kristin Kuutma \& Juris Žigurs \& Kadri Valner (eds.) 75 aastat eesti tantsupidusid. Tallinn: Varrak, pp. 13-18.

Arraste, Angela \& Zajedova, Iivi \& Rüütel, Eha 2011. Rahvatantsuharrastusega seotud kultuuri- ja suurpeod väljaspool Eestit. [Folk Dance Hobby Related Culture and Large Festivals Outside of Estonia.] Mäetagused, Vol. 49, pp. 49-64. Available at http://www.folklore.ee/tagused/nr49/valispeod.pdf, last accessed on July 7, 2013.

Cohen, Sheldon 1991. Social Supports and Physical Health: Symptoms, Health Behaviors, and Infectious Disease. In: E. Mark Cummings \& Anita L. Greene \& Katherine H. Karraker (eds.) Life Span Developmental Psychology: Perspectives on Stress and Coping. Hillsdale, NJ: L. Ehrlbaum Associates, pp. 213-234.

Deci, Edward L. \& Ryan, Richard M. 2000. The "What" and "Why" of Goal Pursuits: Human Needs and the Self-Determination of Behavior. Psychological Inquiry, Vol. 11, No. 4, pp. 227-268, doi:10.1207/S15327965PLI1104_01.

Deci, Edward L. \& Ryan, Richard M. 2008. Facilitating Optimal Motivation and Psychological Well-Being across Life's Domains. Canadian Psychology, Vol. 49, No. 1, pp. 14-23, doi: 10.1037/0708-5591.49.1.14.

Eesti tantsu iseloom 2009 = Eesti tantsu iseloom ja muusika. [Nature and Music of Estonian Dance.] Available at http://www.folk.ee/kultuurilaegas/et/aa_index/rt_ rahvatants_ja_tantsupidu/Eesti-tantsu-iseloom-ja-muusika/Pealkirjata-lehekulg, last accessed on July 7, 2013.

Forrester, Michael (ed.) 2010. Doing Qualitative Research in Psychology: A Practical Guide. London: Sage.

Glaser, Barney G. \& Strauss, Anselm L. 1967. The Discovery of Grounded Theory: Strategies for Qualitative Research. Chicago: Aldine.

Jõe, Heino 1985. Kotkajärve Metsaülikool. [The Forest University at Kotkajärve.] In: Valdu Lillakas (ed.) Eestlased Kanadas II. Totonto: Kanada Eestlaste Ajaloo Komisjon. Available at http://www.eesti.ca/mu/ajalugu, last accessed on June 26, 2013. 
Kangro, Bernard 1976. Eesti Rootsis. Ülevaade sõnas ja pildis. [Estonia in Sweden.] Lund: Eesti Kirjanike Kooperatiiv.

Kapper, Sille 2009. Kuidas uurida eesti rahvatantsu tänapäeval? Teooriatest, meetoditest ja nende rakendamisest Eestis. [How to Conduct Research on Estonian Folk Dance Today? About Theories, Methods and Their Implementation in Estonia.] Mäetagused, Vol. 41, pp. 75-98. Available at http://www.folklore.ee/tagused/nr41/ kapper.pdf, last accessed on July 7, 2013.

Kõiva, Mare 2010. Eestlased ja eesti keel Austraalias. [Estonians and the Estonian Language in Australia.] In: Kristiina Praakli \& Jüri Viikberg (eds.) Eestlased ja eesti keel välismaal. Tallinn: Eesti Keele Sihtasutus, pp. 265-283. Available at http://www.eki.ee/books/eekv/EEKV.pdf, last accessed on June 26, 2013.

Kokla, Juhan \& Raukas, Helga \& Sepp, Reino \& Üürike, Madis (eds.) 1956. Eesti Kroonika 1957: esimene aastakäik. [Estonian Chronicle 1957: The First Year of Issue.] Stokholm: EMP.

Kool, Ferdinand 1999. DP Kroonika: Eesti pagulased Saksamaal 1944-1951. [Estonian Refugees in Germany 1944-1951.] Lakewood, NJ: Eesti Arhiiv Ühendriikides.

McGill, Judith 1996. Developing Leisure Identities. Brampton, Ontario: Brampton Caledon Community Living.

Põldmäe, Rudolf \& Tampere, Herbert 1938. Valimik eesti rahvatantse. [Selection of Estonian Folk Dances.] Eesti Rahvaluule Arhiivi Toimetused 8. Tartu: Eesti Rahvaluule Arhiiv.

Purje, Eerik \& Varangu, Saima 1984. Esto '84: IV Ülemaailmsed Eesti Päevad, 8.-15. juuli 1984, Toronto, Ontario, Kanada. [4th Estonian World Festival, July 8-15, 1984, Toronto, Ontario, Canada.] Toronto: Esto '84.

Raudkats, Anna 1926. Eesti rahvatantsud. [Estonian Folk Dances.] Tartu: Postimees.

Revill, George 2004. Performing French Folk Music: Dance, Authenticity and Nonrepresentational Theory. Cultural Geographies, Vol. 11, No. 2, pp. 199-209, http://dx.doi.org/10.1191/14744744004eu302xx.

Russell, Ruth V. 2009. Pastimes: The Context of Contemporary Leisure. 4th ed. Champaign, IL: Sagamore Publishing.

Ryan, Richard M. \& Deci, Edward L. 2000. Self-Determination Theory and the Facilitation of Intrinsic Motivation, Social Development, and Well-Being. American Psychologist, Vol. 55, No. 1, pp. 68-78, http://dx.doi.org/10.1037//0003-066X.55.1.68.

Shoupe, Catherine A. 2001. Scottish Social Dancing and the Formation of Community. Western Folklore, Vol. 60, No. 2-3, pp. 125-147, http://dx.doi.org/10.2307/1500373.

Snape, Robert 2009. Continuity, Change and Performativity in Leisure: English Folk Dance and Modernity 1900-1939. Leisure Studies, Vol. 28, No. 3, pp. 297-311, http://dx.doi.org/10.1080/02614360903046235.

Strauss, Anselm L. \& Corbin, Juliet M. 1990. Basics of Qualitative Research: Grounded Theory Procedures and Techniques. Newbury Park, CA: Sage Publications.

Toomi, Ullo 1953. Eesti rahvatantsud. [Estonian Folk Dances.] Tallinn: Eesti Riiklik Kirjastus.

Vissel, Anu 2004. Rahvatantsu asendist eestlaste kultuuripildis ja harrastustes. [Folk Dance in Estonians' Culture and Hobby Activities.] In: Ingrid Rüütel (ed.) Pärimusmuusika muutuvas ühiskonnas II. Töid etnomusikoloogia alalt 2. Tartu: Eesti Kirjandusmuuseumi etnomusikoloogia osakond, pp. 109-131. 
Zajedova, Iivi \& Rüütel, Eha 2009. National Cultural Hobby Activities of Estonians in Exile and Their Role as a Means of Preserving Estonianism. Ethnologia Actualis Slovaca (The Journal of Ethnographical Research), Vol. 9, pp. 97-109.

Zajedova, Iivi \& Rüütel, Eha 2012. Comparative Analysis of the Role of Estonians Folk Dance Activity. Faravid. Pohjois-Suomen Historiallisen Yhdistyksen Vuosikirja, Vol. 32, pp. 193-210.

Zajedova, Iivi \& Rüütel, Eha \& Arraste, Angela \& Järvela, Kalev 2009. Rahvatantsuharrastus pagulaseestlaste hulgas ning selle roll eestluse säilimisel. [Folk Dancing among Estonian Expatriates and its Role in the Preservation of Estonian Identity.] Mäetagused, Vol. 41, pp. 99-123. Available at http://www. folklore.ee/tagused/nr41/pagulus.pdf, last accessed on June 26, 2013. 